\title{
Cue Sheets, Musical Suggestions, and Performance Practices for Hollywood Films, I908-I927
}

\author{
Kendra Preston Leonard'
}

Between 1908 and 1927, when sound film became standard, numerous American publications for both those involved in the film industry and the general public, such as Moving Picture World, Motion Picture News, and Exhibitors Herald, included regular columns by cinema conductors, composers, and arrangers such as Samuel Berg, Ernst Luz, and Clarence Sinn for theatre accompanists on selecting and performing music for motion pictures. The earliest of these columns, dating from 1908, primarily argue for or against the inclusion of accompanimental music or discuss what kinds of music - classical instrumental, operatic, and/or popular - are most appropriate (or inappropriate) for the nascent art form. Later articles, however, offer suggestions: general recommendations of pieces to include in accompanying a specific film, and even full-fledged cue sheets, which provide musical references for each major scene in an individual motion picture. These led to the development of the studio-produced cue sheet, issued along with most major pictures. Yet despite claims that moving picture accompanists relied heavily on these cue sheets, archival materials suggest that they were more often used as jumpingoff points for compiled scores created by accompanists, or were ignored altogether in favour of scores compiled from an accompanist's or theatre's existing music library or other resources. In this chapter, I examine the use of cue sheets found in several North American collections, demonstrating how cue sheets were actually used by accompanists at some of the largest motion picture palaces of the 1920s.

By 1908, after many film-makers moved from New York to Hollywood to avoid the control wielded over the industry by the monopolistic Motion Picture Patents Company, the cinema industry had largely decided that accompanying a motion picture with music was not only acceptable, but essential. Although debates about what kinds of music were appropriate for film lasted well into the sound era, directors, producers, critics, and performers all agreed that accompanimental music served a narrative function and assisted in establishing geographical, chronological, and other loci, both acousmatically and within the diegesis of the medium. As a result, trade magazines and studios began publishing suggestions for music to be used with particular films. The Edison 
Kinetogram, the house organ for the inventor's studio, began offering columns on 'playing the picture' starting in 1909. As Martin Miller Marks has noted, the suggestions from Edison were not terribly sophisticated: the recommendations for a nine-scene film titled How the Landlord Collected His Rent were: '1. March, brisk; 2. Irish jig; 3. Begin with Andante, finish with Allegro; 4. Popular Air; 5. Ditto; 6. Andante with Lively at finish; 7. March (same as No. 1); 8. Plaintive; 9. Andante (Use March of No. 1).'2 But as Julie Hubbard has written, the Kinetogram's pioneering column spurred other film companies and magazines to publish their own suggestions as well. Film Index and Moving Picture World began publishing columns in 1910. ${ }^{3}$ There was a significant increase in the number of films for which musical suggestions (sometimes called 'musical plots') were made in trade magazines during the late 1910s and early 1920s. Such suggestions led to the development of the studio-published cue sheet. Cue sheets, which offered more specific pairings of an individual piece of music with each scene, became more detailed over time, frequently including not just titles of chosen pieces, but also musical incipits. The cue sheets of the 1920 s represent the height of the form. Composers, music editors, and score compilers, including Max Winkler, Ernst Luz, and James C. Bradford, contributed to both trade magazines' musical suggestions and created stand-alone publications that were distributed by studios with their films as part of an attempt by studios to control or at least influence the musical accompaniment of their pictures.

Although such recommendations were, as Bradford had printed at the top of his cue sheets for Paramount, mere aids for music directors, 'their purpose [being] rather to illustrate the style and character of the music that fits each scene and so enable the leader to select a similar piece from his library,' the studios - which often owned the publishing companies that produced the music - heavily promoted the recommended pieces. ${ }^{4}$ Advice columns for accompanists published in industry trade journals - written by the same composers and arrangers listed above - also advocated for the acquisition of cue sheet-referenced pieces on cinema musicians, claiming them as essential for the sophisticated cinema music library. Regarding these practices, Rick Altman writes, 'during the twenties, music directors and orchestra leaders depended heavily on cue sheets', and 'selections chosen by cue sheet compilers were guaranteed continued sales and playing time. ${ }^{5}$

There is very little published documentation about exactly how and when these musical cues were used. ${ }^{6}$ Comparisons between cue sheets and the actual music played, as described in reviews, shed some light on performance practices of the silent cinema. However, most reviews of photoplaying were written about only the largest theatres, such as the Rialto in New York, where the performers were the self-same authors of the cue sheets. Even there, however, there was clearly room for deviation from the cue sheet, as I demonstrate below. Here, I analyse the use of cue sheets and their supplantation by performer-compiled scores, arguing that while Hollywood compilers may have inspired accompanists in their choices of photoplay music, accompaniments 
for studio films were highly individualised and determined by a player's own preferences and available music library. I examine archival materials belonging to three professional accompanists: cue sheets, scores, photoplay albums, sheet music, and more used by Hazel Burnett (1892-1973), located in the Josephine Burnett Collection at the Harry Ransom Center at the University of Texas at Austin, cue sheets and scores owned by Claire H. Hamack (c.1898-1977), and cue sheets owned by Adele V. (Della) Sullivan (née Overbeck, c.1883-1964), which comprise the Silent Film Collection held by the American Music Research Center (AMRC) at the University of Colorado Boulder.

That the accompanists I name here are all women is not unusual. In 1914, the manager of a thriving silent cinema wrote that having a successful theatre often depended on being able to provide 'good music . . furnished in the way of an accomplished [female] pianist'? The job of cinema accompanist was a respectable one for women, and was compared positively with secretarial work, teaching, and nursing. The presence of a female accompanist indicated that a cinema was intent on being an artistic and moral institution, especially as the film industry worked to establish itself as a legitimate business producing respectable and creative works. Although no census of cinema accompanists was ever taken, reports from trade and industry publications suggest that while white male musicians were in the majority in the earliest days of cinema accompaniment, women, both white and of colour, soon outnumbered them. Women certainly comprised the majority of cinema accompanists after the spring of 1914, when all-male cinema orchestras were dissolved so that their members could join the military. As Ally Acker has written about women in the silent film industry, 'women are as integral and transformative to the cinema as [well-known men], and yet their stories have consistently remained untold'. ${ }^{8}$ In an era when women were often named only as 'Miss [last name]' or 'Mrs [husband's last name]' in print, and those who wished to publish music still often had to do so under pseudonyms or with their first initials in place of their names in order to be considered seriously, only a limited number of female composers and performers were made easily identifiable or recognised for their work. The influence of these women, particularly during the Great War and its immediate aftermath, cannot be understated; as Acker continues, 'more women worked in decision-making positions in film before 1920 than at any other time in history'. Acker's claim certainly includes female musicians. Women accompanists, who came from a wide variety of socio-economic strata and had equally diverse musical backgrounds and educational experiences, became the arbiters of musical taste and overall morality in movie theatres, as a place where a woman played was deemed appropriate for other women and children. Working in cinema music, women took on roles as performers, composers, inventors, and innovators within the film industry, their responsibilities often overlapping and becoming inextricably entwined. It is clear from interviews of accompanists and audience members and recent research that these musicians' performances for newsreels, animations, live-action shorts, 
and feature films served in multiple ways. Their accompaniments, which used already existing music, new compositions by themselves and others, and their own improvisations, shaped and helped define the musical sensitivities of the time. Accompanists created music and approaches to using music that would become part of the audience's expectations for film music, established musical standards for film scores that would carry through into sound films, educated listeners as to different types of music and musical genres, and to musical traditions relating to affect and meaning, and demonstrated how music could serve as a narrative and interpretative force in the cinema.

Just as full scores issued by studios for films were often jettisoned for simpler and/or easier-to-play compilations, cue sheet versions, abridgements, or arrangements, cue sheets were likewise modified, used merely as the basis for ideas, or even ignored. ${ }^{10}$ As Rodney Sauer has noted, 'Many surviving cue sheets, including the two reproduced in [Gillian] Anderson['s book] show multiple changes from the printed score pencilled in by a theatre music director. ${ }^{\text {'11 }}$ Such is the case with the cue sheets from the Burnett, Sullivan, and Hamack collections. The modular format of the cue sheet allowed for easy substitution of a performer's preferred pieces in the place of those suggested by the cue sheet compiler. In every case of cue sheets in the Burnett Collection and the Silent Film Collection at Boulder, the editor of the cue sheet appears to have made changes to incorporate repertoire they already owned and knew.

Hazel Burnett performed for both cinema and live theatre as an organist and pianist. After an early career in Ohio, she moved to Texas, where she played at the Majestic Theater in Austin and the Queen Theater and the Aztec Theatre in San Antonio. The Burnett Collection contains a wide variety of materials, including printed cue sheets and full scores, photoplay albums, sheet music, and hundreds of pieces clipped out of The Etude and Melody magazines. Much of Burnett's music is marked with performance indicia that confirm that she used it in accompanying silent film. Burnett also drew heavily on the repertoire from the stage in scoring movies.

Burnett's cue sheets are mostly unmarked and appear to have been used only as guides for her to compile her own scores, which she did using music from albums and magazines. Numerous pieces of sheet music in her collection are labelled with cue numbers and descriptive notes: Frederick Vanderpool's 'The Want of You' was used for the cue 'maw asleep' in one unidentified movie, and Edvard Grieg's popular 'Ase's Death' accompanied another unknown film's cue 27: 'Mary prostrated'. 'No. 5 Molto Agitato' from Breil's Original Collection of Dramatic Music for Motion Picture Plays is marked as ' 14 phone rings', while 'No. 6 Andante Misterioso' was used for '[Cue] 2[:] man enters'. Burnett wrote the titles of accompaniment-appropriate pieces on the covers of the photoplay albums that contained the pieces, often including the page number for quick access. She also interleaved pieces of sheet music and pieces cut from Melody and The Etude between pages of her photoplay albums to create original modular scores. 
One particularly useful example for understanding Burnett's practices is her compiled score for the 1920 Paramount movie Humoresque. The film is a classic melodrama about a young Jewish violinist. Hugo Riesenfeld composed an original score for Humoresque for the film's premiere, and it was this score that was performed by a cinema orchestra and organist at its premiere and on the road tour that followed. While Burnett almost certainly had access to Riesenfeld's cue sheet, she compiled a rather different score from her own personal library while retaining two pieces recommended both by the editors of American Organist magazine and Riesenfeld.

In August 1920, American Organist, hoping to publish but not yet having secured the official cue sheet from Riesenfeld, proposed its own set of musical suggestions for Humoresque. 'In suggested classic organ scorings for photoplays', the anonymous author wrote:

we shall depart from the hodge-podge method of using two or three dozen pieces, confining ourselves instead to the selection of only a few outstandingly appropriate organ numbers, and using them as motives upon which the background of the music is to be woven. ${ }^{12}$

The pieces chosen were:

[Charles Marie] Widor's Andante Cantabile Af[fectuoso] (Sym. 4): illustrating the home life, its nobility of character, its pathos, its sincerity; and also these characteristics as portrayed in the hero;

[William] Wolstenholme's 'The Answer': illustrating the love of her and heroine;

Wolstenholme's 'The Question': illustrating the excitement and the uncertainty of the crucial situations;

[Antonin] Dvorak's 'Humoresque': the piece the hero is apparently supposed to use for his greatest performances;

Max Bruch's Kol Nidre: optional in concert before his own people; and for the Mother's devotions in the Synagogue;

(Traditional: 'Eli Eli': as above). ${ }^{13}$

On the very next page, however, the editors of the magazine's Photoplay Department offered a slightly different set of suggested pieces, gleaned from attending a showing of the picture where Riesenfeld's compiled score had been used. Here, they re-recommended Dvorak's 'Humoresque', 'Eli Eli', and Bruch's Kol Nidre, but instead of the Widor and Wolstenholme pieces advised the use of Francis Dorel's 'Love Bells', Felix Mendelssohn's 'Athalia Selection', and Cecile Chaminade's 'Serenade'. ${ }^{14}$ In the next month's issue, there appeared responses and additions to the suggestions from August: cinema organist Rollo F. Maitland pointed out that 'Eli Eli' was not, in fact, a traditional Jewish melody, but was heavily based on 'Through the Ages' by Josiah Zuro and had been 
composed for a 'Hebrew' stage play by J.K. Sandler, after which it was adapted for several dramatic productions on both stage and screen. ${ }^{15}$ Furthermore, by this time, American Organist had obtained Riesenfeld's own official cue sheet for the film, which it published in full but without musical incipits, or the first few bars of the piece of music, showing the primary melody, in the issue. (For the full cue sheet, see Table 2.3 at the end of this chapter.)

In addition to the pieces listed above, Riesenfeld's selections also included several pieces from the collection Hebrew Songs and Dances ${ }^{16}$ and works by Ole Bull, Paul Lacôme, and Riesenfeld himself. ${ }^{17}$ Despite the publication of his cue sheet for the film - said to be the first of his cue sheets ever made available to 'any but his own conductors and organists'18 - Riesenfeld made several changes to the cues even while the film played in New York, depending on the theatre in which it was shown. Such variation directed by the compiler himself suggests that he knew that his cues would ultimately serve as general guidelines rather than a fixed work to which cinema musicians would rigidly adhere. The Musical Courier traced the use of Riesenfeld's cues for Humoresque, focusing on the overture as an example of how the cue recommendations might be altered:

When the picture was shown at the Criterion, Mr. Riesenfeld selected Dvorak's 'Humoresque' as the overture for the reason that that famous composition was ideal for the intimate orchestra at the little playhouse. Yet, when the photodrama was moved to the Rivoli Theater, Goldmark's 'Sakuntala' overture was played by the Rivoli musicians because it lent itself better for the larger group. And, when 'Humoresque' moved to the Rialto, the mallet music from Goldmark's 'Queen of Sheba' was chosen as the overture, a composition which had the Oriental atmosphere, ${ }^{19}$ yet different from that played at the Rivoli. ${ }^{20}$

At other screenings of Humoresque at the Rivoli, Riesenfeld used an unidentified overture by Weber to introduce the film. ${ }^{21} \mathrm{With}$ overtures proving mutable, Riesenfeld established musical continuity through the use of the 'Jewish-sounding' 'Eli, Eli', sung by Emanuel List and Jean Booth at the premiere, and the various pieces from 25 Hebrew Songs and Dances. The reviewer for American Organist praised Riesenfeld's score for its mix of 'authentic' and 'effective' music, writing, 'the Jewish music was well registered and never became tiresome'. ${ }^{22}$

Burnett included two of Riesenfeld's musical choices for the picture, Dvorak's 'Humoresque' and Bruch's Kol Nidre. Assigning credit for her use of these pieces exclusively to Riesenfeld's cue sheet is impossible; however, the titular work could hardly be avoided, and Bruch's arrangement of the traditional Kol Nidre was a well-known musical synonym for Jews. Nonetheless, her score has these commonalities with Riesenfeld's, even as 
she replaced the remainder of Riesenfeld's suggestions. Burnett wrote out her cues and notes for accompanying the film on the inside front cover of her 1917 Standard Student's Classic Album, from which some of the cues were drawn, demonstrating that she created her score from music she already owned and knew. ${ }^{23}$ She combined the music for some continuous or closely related cues, reducing the number of different works in her score and providing scene-to-scene continuity in addition to that delivered by the two main themes (ss Table 2.1).

Burnett also employed leitmotifs in her score in more consistent ways than Riesenfeld. While Riesenfeld uses different pieces from 25 Hebrew Songs and Dances - not far from American Organist's disdained 'hodge-podge method of using two or three dozen pieces' - each time the camera returns to the protagonist's home, enters the temple, or otherwise shows the exterior signifiers of Judaism, Burnett uses only the Kol Nidre; the frequency of its use is eclipsed only by 'Humoresque' itself, which she also uses far more often than Riesenfeld does. Her reiterated uses of 'Humoresque' and the Kol Nidre provide solid, recognisable themes for the picture, the 'motives upon which the background of the music is to be woven.' At the same time, the other pieces listed in her cue sheet (see Table 2.2) repeatedly share rhythmic and melodic gestures and key areas, contributing to a holistic and coherent score that adheres to the contemporary aesthetic of using leitmotifs as narrative devices in film scoring.

Although some of these cues may be unknown today, Burnett's albums reveal them to be popular and well-known works frequently heard in the cinema. These selections denote Burnett's familiarity with audience expectations

Table 2.I Riesenfeld's cues I-5 and Burnett's cues I-5 for Humoresque (I920)

\begin{tabular}{|c|c|c|}
\hline Cue & Riesenfeld & Burnett \\
\hline I-D (Opening) & $\begin{array}{l}\text { Athalia selections (Mendelssohn/ } \\
\text { Fischer) }\end{array}$ & Kol Nidri [sic] \\
\hline 2-T 'Its Ghetto Echoing’ & $\begin{array}{l}\text { 'Dobrydaien Dance' (No. } 2 \text { in } \\
\text { Hebrew Songs and Dances/ } \\
\text { Fischer) }\end{array}$ & 'Melodie' (Huerter) \\
\hline 3-T 'In This' & Hebrew Songs and Dances, No. 21 & $\begin{array}{l}\text { 'Blue Ribbon Caprice' } \\
\text { (Engleman) }\end{array}$ \\
\hline $\begin{array}{l}\text { 4-T 'While in the } \\
\text { Tenement Above' }\end{array}$ & $\begin{array}{l}\text { 'Hebrew Wedding Ceremony', } \\
\text { from 2nd mvt. of Andante } \\
\text { Moderato (M. Akst/Lohr) }\end{array}$ & $\begin{array}{l}\text { 'In a Canoe' } \\
\text { (Zamecnik) }\end{array}$ \\
\hline $\begin{array}{l}\text { 5-T 'Rudolph, Come Up } \\
\text { Here' }\end{array}$ & Same as No. 3 & 'June Rose' (Cadman) \\
\hline
\end{tabular}

Note: 'D' refers to a direction cue or action; ' $T$ ' refers to the text of an intertitle. Punctuation modernised for clarity. 
Table 2.2 Hazel Burnett's cue sheet for Humoresque (1920)

Cued Music [meaning music appearing in the film's diegesis]: Humoresque Humoresque-Overture

I. Kol Nidri [sic]

2. Melodie - Huerter

3. Blue Ribbon - Caprice-Engelmann

4. In a Canoe - Zamecnik

5. June Rose - Cadman

6. Water Lilies - St Clair

7. Humoresque - Direct cue

8. O sole mio

9. Funiculi-Funicula - Day in Venice

10. Legend of a Rose - Reynard

I I. Kol Nidri - Direct cue

12. Humoresque - Direct cue

13. Hop - Reidel

14. Mood Pensive - Applefield

15. Good bye - Tosti

16. Kol Nidri - very short - in temple

17. March - bright

18. Sonata - Pathetic - Beethoven

19. Melodie-Massenet

20. Spring Song - Mendelssohn

21. Hungarian Rhapsody

22. Humoresque

Finale - March - Bright

and the extramusical associations such pieces had developed from being used to accompany stage and screen works. Jules Massenet's 'Melodie', for example, is the composer's 'Melodie-Élégie' Op. 10, No. 5 (from the composer's Pièces de genre; also used in his incidental music to Les Érinnyes) and was commonly used in cinema accompaniments to indicate sadness. F. Paolo Tosti's 'Good Bye', likewise, was a favourite of audiences around the turn of the century and included in Albert Ernst Wier's The Ideal Home Library, Vol. 9, published by Scribner in 1913. Other pieces, such as those by Mendelssohn and Beethoven, were commonly found in photoplay albums; works by J.S. Zamecnik and Charles Huerter were composed specifically for film accompaniment.

Many of the pieces Burnett used in her compiled score for Humoresque and other scores were drawn from The Etude magazine, which published numerous short generic or character pieces in each issue. Such works, available at a lower cost than individually published pieces of sheet music, made up an expansive library of music appropriate for playing with moving pictures. In compiling a score, Burnett often attached these pieces, cut out of the magazine, to other pieces, handwritten cue sheets, or notes indicating their place in a film score. 
'Merry Hunting Party' by Emil Söchting is marked as being for 'Calamity Jane' (see Figure 2.1); other pieces Burnett clipped out of The Etude to use in accompanying include Frank H. Grey's 'Shadow Land', Carl Wilhelm Kern's 'España (Bolero)', and hundreds more. Other materials in the Burnett Collection suggest that while Burnett may have taken inspiration from, or adopted, a few musical suggestions from cue sheets, her accompanimental practices did not make much use of the music advised by them. Thus, audiences in Ohio and Texas who experienced her cinematic accompaniments would have heard her original musical interpretations of Hollywood films, and not those proposed by studio cue compilers.

The AMRC's Silent Film Collection contains heavily modified cue sheets that are, in effect, modular scores like Burnett's in which a few elements of the cue sheet may be retained, but the bulk of the music is replaced by pieces in the accompanist's library. Materials owned by accompanist Claire H. Hamack include 58 cue sheets both with and without musical incipits by various compilers and from all of the major Hollywood studios, many of them annotated by Hamack. Hamack's studio-issued cue sheet for the 1925 United Artists film Stella Dallas (directed by Henry King), for example, lacks incipits but does list cue number, length of cue, title or dialogue cue, piece title and composer name, and colour according to Ernst Luz's 'Symphonic Color Guide' for organising silent film scores, all useful information in finding an appropriate replacement from Hamack's own music library. For some of the suggestions in Stella Dallas, such as using 'Songs My Mother Taught Me' (Dvorak, arr. Fischer), Hamack made a check mark near the title, indicating that she had or knew the music and found it suitable. At the top of the cue sheet, though, she listed a number of other pieces to use in accompanying the film, including 'Somewhere a

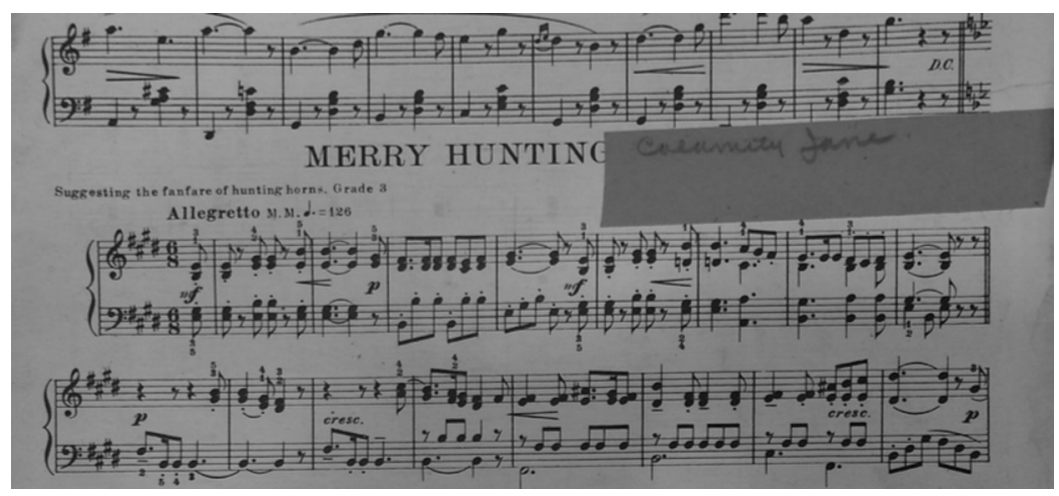

Figure 2.I Hazel Burnett's annotation indicating that 'Merry Hunting Party' was to be used for the character of Calamity Jane in the 1915 picture In the Days of '75 and '76

Source: Photo by Kendra Preston Leonard. 
Voice is Calling', 'I'm Drifting Back to Dreamland', Bruch's Violin Concerto, and the Andante from Tchaikovsky's Fifth Symphony. In a similar text-only cue sheet by Bradford for When Knighthood was in Flower (Robert G. Vignola, 1922), Hamack replaced suggested themes by William F. Peters and Massenet with Franz Schubert's 'Moment Musical', Edwin Lemare's 'Meditation', and other selections. She specifically wrote over the printed titles for cue 5, 'While Mary dreamed', changing it from 'Serenade Romantique' by Gaston Borch to 'Wakey Little Bird', and changing the music for cue 11, 'It is near to midnight', from 'Romance - German (The Conqueror)' to Grieg's 'Dawn' from Peer Gynt. The cue sheet for The Dangerous Age, a 1927 German film directed by Eugen Illés, is covered with Hamack's notes, including notation for an alternate, possibly original, theme, and indications that suggestions were replaced with other works ('In the Gloaming' is preferred over Otto Langey's 'Dream Shadows' for cue 23). Other cue sheets, including that for My American Wife (directed by Sam Wood, 1922), also bear short passages of handwritten notation for original themes and motifs. Hamack's audiences, like Burnett's, would have heard Hamack's musical interpretation of the film rather than that of the studio compiler (see Figure 2.2).

Hamack clearly found some of the published cue suggestions useful, and her accompaniments were hybrids of published cues and her own selections, drawn primarily from photoplay albums and sheet music. She used several pieces from the Bosworth Loose Leaf Film Play Music Series vol. 2, Chas. L. Johnson's Picture Show Music, and Emil Velazco's Komedy Kartoons series. The cue sheets that show evidence of being the most highly used - judging

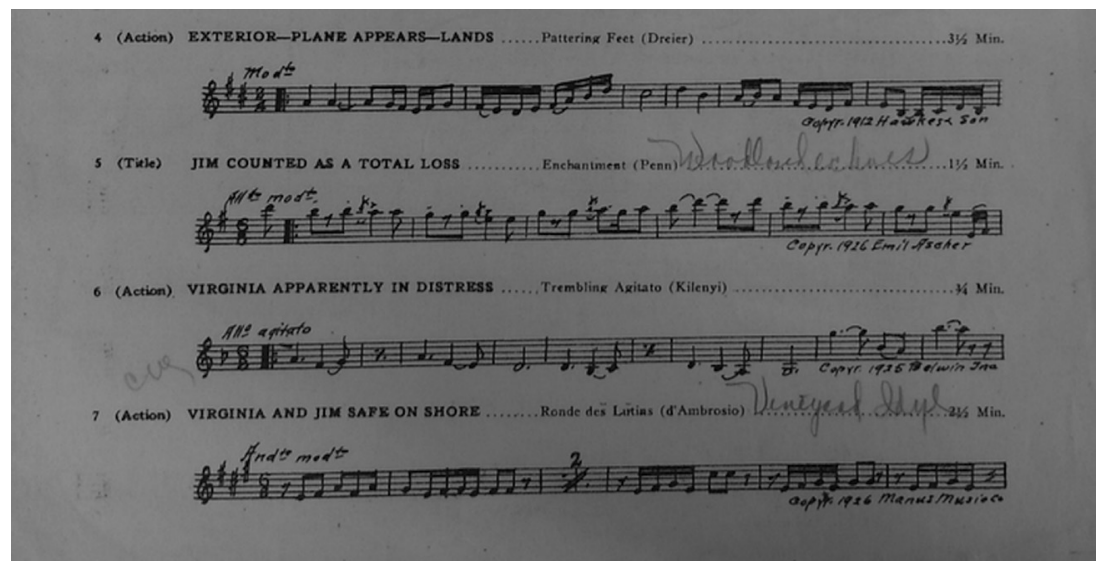

Figure 2.2 Claire Hamack's replacements for cues in The Lodge in the Wilderness (directed by Henry McCarty, 1926), substituting 'Woodland Echoes' for cue 5 and 'Vineyard Idyll' for cue 7

Source: Photo by Kendra Preston Leonard. 
by smudges, folds, and the need for taping pages back together - are those that Hamack edited the most, reusing material as appropriate. In one case of radical repurposing, it appears that Hamack used a heavily hand-edited cue sheet issued for Men of Steel (directed by George Archainbaud, 1926) to accompany the silent release of The Vagabond King (directed by Ludwig Berger, 1930).

Many of Adele V. Sullivan's 41 cue sheets at the AMRC are seemingly unused. A few are marked with only the occasional date or whether the film for which the cue sheet was issued was a 'talker': Halfway to Heaven (directed by George Abbott), for example, was released in December of 1929 by Paramount with some sound dialogue, but was also issued to exhibitors with a cue sheet of incipits compiled by Bradford. But other cue sheets are, like Hamack's, heavily edited. On the cue sheet for Modern Matrimony (directed by Lawrence C. Windom, 1923), Sullivan replaced almost every printed cue with a new title of her own, using the cue sheet as a cue list from which she created her own modular score. She even pasted the music for her preferred love theme for the movie - Carl Kiefert's 'Song Orientale' - onto the cover of the cue sheet. Similarly, Sullivan revamped the cue sheet for The Ten Commandments (directed by Cecil B. DeMille, 1923); rather than using the provided incipits, she wrote in page numbers and titles from an unknown photoplay album or albums, replacing a number of the printed cues. ${ }^{24}$ She also used Homer Grunn's Desert Suite: Five Tone Pictures for the Piano (1913) and selections from various Victor Herbert musicals as music for accompanying silent film. For pictures needing bugle calls, patriotic music, and military marches, she also ignored the provided cues from cue sheets, using instead 'Reveille' and short pieces from G. Martaine's 1914 Academic Edition photoplay album; she replaced other cues with generic pieces from albums published by Sam Fox, Walter Jacobs, and B.F. Wood (see Figure 2.3).

Sullivan was also responsible for synchronising the playing of records with the projection of a number of films as well, and in these cases too she often substituted her own selected recordings for the studio-specified pieces. She replaced almost every piece indicated on a typewritten cue sheet for All at

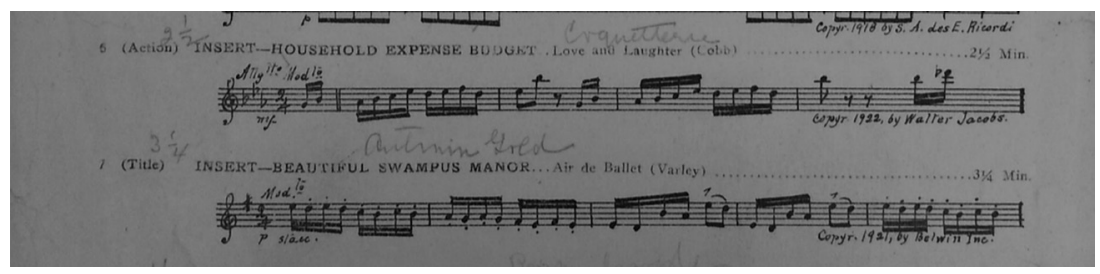

Figure 2.3 Della Sullivan's notes for substitutions for Modern Matrimony Source: Photo by Kendra Preston Leonard. 
Sea (directed by Alfred J. Goulding, 1929) with other works, unfortunately indicated only by Sullivan's own system of numbers and letters. It is also very likely, based on the markings on some of the recording cue sheets, that she played a live accompaniment rather than using records, relying on the recording cues as timing and genre guides.

These documents, used in major moving picture houses by professional cinema musicians, reveal that accompanists, particularly those with considerable experience and their own music libraries, made creative use of cue sheets. The accompanists' use of cue sheets aligns with Bradford's disclaimer that his suggestions did not imply that a cinema music director should 'purchase the pieces suggested nor should it be inferred that without them a good musical setting is not possible,' and refutes claims by Altman and Shana Anderson that the publications were meant to be followed precisely. ${ }^{25}$ Furthermore, the reception of accompaniments in which studio compiler-dictated cues were replaced by other selections is almost never negative; neither reviewers nor audiences policed the use of cue sheets, suggesting that not only were performercompiled scores unproblematic, but they were often expected. Indeed, testimony from organists such as Rosa Rio agrees that performers for silent films often used cue sheets as starting places for building a score, created compiled scores from their own libraries, and continued to improvise throughout the 1910s and 1920s, despite Anderson's claim that 'by 1920, arbitrary improvisation was unacceptable. ${ }^{26}$

These artefacts of early film music history provide us with valuable, previously unexcavated information. Cinema accompanists frequently used cue sheets as tools for timing and possibly inspiration rather than actually playing from them, and accompanists playing for Hollywood films in various areas of the United States constructed personal cue sheets and modular scores based on the contents of their own music libraries. In working with their own extant libraries, accompanists probably did not have as much of an economic influence on the sales of sheet music as Altman suggests. In fact, based on the evidence of these and other edited cue sheets, accompanistcompiled scores, and the fact that cinema musicians continued to improvise (either using original leitmotifs and themes, such as Rio did, or more freely) until the adoption of integrated sound, I propose that the accompanists themselves, as opposed to the cue sheet compilers, were the primary arbiters of taste and trends in silent film music. As a result, the accompaniments for Hollywood silents were certainly far more diverse than those compiled by studio musicians, and reflected accompanists' personal tastes and those of their audiences much more closely than did generic studio-issued cue sheets. These accompanimental practices hint at a wealth of yet undiscovered musical treatments that undoubtedly influenced how silent films were received and interpreted. 
Table 2.3 Hugo Riesenfeld's cue sheet for Humoresque (1920) (as punctuated in 'Riesenfeld's “Humoresque” Score', American Organist, September $1920,332)$

\begin{tabular}{|c|c|}
\hline Cue & Piece \\
\hline I-D (Opening) & $\begin{array}{l}\text { Athalia Selections, Mendelssohn } \\
\text { (Fischer) }\end{array}$ \\
\hline 2-T Its Ghetto Echoing & $\begin{array}{l}\text { Dobrydzien Dance (No. } 2 \text { in } \\
\text { Hebrew Songs and Dances) } \\
\text { (Fischer) }\end{array}$ \\
\hline 3-T In This & Hebrew Songs and Dances No. 2I \\
\hline 4-T While in the Tenement Above & $\begin{array}{l}\text { Hebrew Wedding Ceremony, } \\
\text { from 2d Mvt. of Andante } \\
\text { Moderato, M. Askt (Lohr) }\end{array}$ \\
\hline 5-T Rudolf, Come Up Here & Same as No. 3. \\
\hline 6-D Close-up of Sick Boy & Same as No. 4 \\
\hline 7-T Like a Little Scraggly Plant & $\begin{array}{l}\text { Love Bells Intermezzo, Francis } \\
\text { Dorel (Boosey) }\end{array}$ \\
\hline 8-D Boys Surround Leon & Agitato (manuscript) \\
\hline $\begin{array}{l}\text { 9-D After the Fight when Leon Goes } \\
\text { Away }\end{array}$ & Same as No. 7 \\
\hline I0-D Jewish Home is Seen Again & $\begin{array}{l}\text { Nos. 5, 6, and } 7 \text { of Hebrew Songs } \\
\text { and Dances }\end{array}$ \\
\hline II-T It's Come, Abraham & Same as No. 4 \\
\hline I2-T It's like a Pain & $\begin{array}{l}\text { No. } 7 \text { of Hebrew Songs and } \\
\text { Dances }\end{array}$ \\
\hline $\begin{array}{l}\text { I3-D Family Begins to Eat } \\
\text { I4-D Close-up of Mother After She } \\
\text { Brings Violin }\end{array}$ & $\begin{array}{l}\text { No. } 18 \text { of Hebrew Songs and Dances } \\
\text { Same as No. } 4\end{array}$ \\
\hline I5-D Little Gina is Seen & $\begin{array}{l}\text { Saeterjentens Sondag Melody, Ole } \\
\text { Bull (Fischer) }\end{array}$ \\
\hline I6-D Mother Comes Home with Violin & Same as No. 4 \\
\hline I7-D Temple Scene & Sakuntala, Goldmark (Schirmer) \\
\hline 18-D Boy Plays Violin & Selection from a Grieg Sonata \\
\hline 19-D King Gets Up & Mascarade, P. Lacome (Enoch) \\
\hline 20-D Moonlight, Venice & Same as No. 7 \\
\hline $\begin{array}{l}\text { 2I-T When the Kantors Returned to } \\
\text { America }\end{array}$ & Tete-a-Tete, De Koven (Schirmer) \\
\hline 22-T A Great Unrest had Torn & Serenade, Chaminade (Schirmer) \\
\hline 23-T This was Leon's Final Seal & $\begin{array}{l}\text { Queen of Sheba Selections, } \\
\text { Goldmark (Fischer) (First I4 } \\
\text { bars of Ballet Suite, then to } \\
\text { Lento after sign G in D flat, as } \\
\text { arranged by Hugo Riesenfeld } \\
\text { and published by Schirmer) }\end{array}$ \\
\hline
\end{tabular}


Table 2.3 (continued)

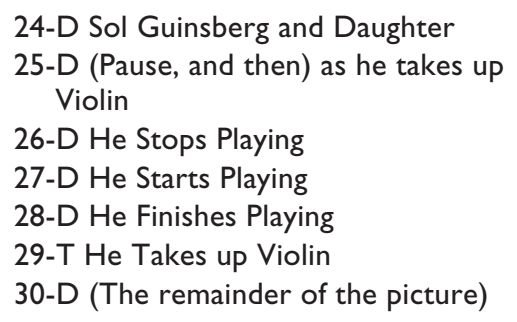

24-D Sol Guinsberg and Daughter

25-D (Pause, and then) as he takes up Violin

26-D He Stops Playing

27-D He Starts Playing

28-D He Finishes Playing

29-T He Takes up Violin

30-D (The remainder of the picture)

\author{
Schumann Suite Selections \\ Kol Nidre, Bruch (Jungnickel) 4 \\ bars also at sign A (Schirmer) \\ Organ* \\ Humoresque, Dvorak \\ Organ \\ Humoresque, Dvorak \\ Organ
}

Note: * According to American Organist, 'The organist replaced the orchestra at No. 26 and finished the picture, the respective players being at liberty to arrange their own scores, following the materials already scored by Mr. Riesenfeld for the main portions of the picture.'

\section{Notes}

1 My thanks to Jonathan Mummolo and Rachel Barker-Asto for their assistance in locating and providing archival materials for this essay.

2 Martin Miller Marks, Music and the Silent Film: Contexts and Case Studies, 1895-1924 (New York: Oxford University Press, 1997), 68.

3 Julie Hubbert, Celluloid Symphonies: Texts and Contexts in Film Music History (Berkeley, CA: University of California Press, 2011), 7.

4 Bradford's cue sheets for Paramount stated: 'The purpose of this musical setting is to aid the leader in selecting appropriate music for the picture. It is not intended that he should purchase the pieces suggested nor should it be inferred that without them a good musical setting is not possible. Their purpose is rather to illustrate the style and character of the music that fits each scene and so enable to leader to select a similar piece from his library.'

5 Rick Altman, Silent Film Sound (New York: Columbia Press: 2004), 353-4.

6 One exception is Marco Targa, 'The Use of Cue Sheets in Italian Silent Cinema: Contexts, Repertoires, Praxis', in The Sounds of Silent Films, ed. Claus Tieber and Anna Windisch (New York: Palgrave Macmillan, 2014), 49-65.

7 Anon., Motion Picture Magazine, July 1914, 102-3.

8 Ally Acker, Reel Women: Pioneers of the Cinema, 1896 to the Present (New York: Continuum, 1991), xvii.

9 Ibid., xviii.

10 Kendra Preston Leonard, 'Using Resources for Silent Film Music', Fontes Artis Musicae 63, no. 4 (October-December 2016): 274.

11 Rodney Sauer, 'Photoplay Music: A Reusable Repertory for Silent Film Scoring, 1914-1929,' American Music Research Center Journal 8-9 (1 January 1998): 56. The book he cites here is Gillian Anderson, Music for Silent Films, 1894-1929: A Guide (Washington, DC: Library of Congress, 1988), xxx, 32.

12 'Score in Detail: Humoresque', American Organist, August 1920, 295.

13 Ibid. Modern punctuation added for clarity.

14 Ibid., 296.

15 Rollo F. Maitland, 'The Humoresque Score', American Organist, September 1920, 331.

16 J. Fleischmann, 25 Hebrew Songs and Dances (New York: Fischer, 1912).

17 'Riesenfeld's "Humoresque" Score', American Organist, September 1920, 332. 
18 Ibid.

19 Jews, Jewish topics, and Jewish customs were often referred to as 'Oriental' during this period. For more, see Ivan Davidson Kalmar and Derek Penslar, eds., Orientalism and the Jews (Boston, MA: Brandeis University Press, 2004).

20 'Films Must Be Artistically Introduced', The Music Magazine-Musical Courier 81, 16 September 1920, 36, 39.

21 'Reel Life at the Riesenfeld Houses', Columbia Daily Spectator, 19 July 1920, 3, accessed 13 July 2016, http://spectatorarchive.library.columbia.edu/cgi-bin/colum bia? $=\mathrm{d} \& \mathrm{~d}=\mathrm{cs} 19200719-01.2 .22$.

22 'Photoplay Reviews: Rialto - New York', American Organist, September 1920, 332.

23 Standard Student's Classic Album (Philadelphia, PA: Theodore Presser, 1917).

24 Marginalia suggests that Sullivan used at least one album published by Belwin; other pieces included the 'Pilgrim March' by Frederick Scotson Clark and 'Love's Old Sweet Song' by James Lynam Molloy.

25 Shana Anderson, 'Ideal Performance Practice for Silent Film: An Overview of How-To Manuals and Cue Sheet Music Accompaniment from the 1910s-1920s' (PhD diss., University of Ottawa, 2013, abstract); and Rick Altman, Silent Film Sound, 371.

26 Anderson, 'Ideal Performance Practice'.

\section{Bibliography}

\section{Archives}

Josephine Burnett Collection. Harry Ransom Center, University of Texas at Austin.

Silent Film Collection. American Music Research Center, University of Colorado Boulder.

\section{Print}

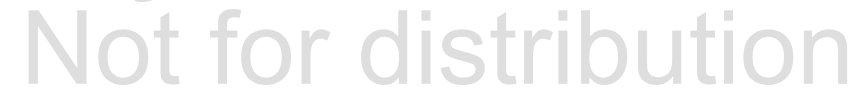

Acker, Ally. Reel Women: Pioneers of the Cinema, 1896 to the Present. New York: Continuum, 1991.

Altman, Rick. Silent Film Sound. New York: Columbia University Press, 2004.

Anderson, Gillian. Music for Silent Films, 1894-1929: A Guide. Washington, DC: Library of Congress, 1988.

Anderson, Shana. 'Ideal Performance Practice for Silent Film: An Overview of How-To Manuals and Cue Sheet Music Accompaniment from the 1910s-1920s'. PhD diss., University of Ottawa, 2013.

Anon. Motion Picture Magazine, July 1914, 102-3.

Davidson Kalmar, Ivan, and Derek Penslar, eds. Orientalism and the Jews. Boston, MA: Brandeis University Press, 2004.

'Films Must Be Artistically Introduced'. The Music Magazine-Musical Courier 81, 16 September 1920, 36, 39.

Fleischmann, J. 25 Hebrew Songs and Dances. New York: Fischer, 1912.

Hubbert, Julie. Celluloid Symphonies Texts and Contexts in Film Music History. Berkeley, CA: University of California Press, 2011.

Leonard, Kendra Preston. 'Using Resources for Silent Film Music'. Fontes Artis Musicae 63, no. 4 (October-December 2016): 259-76. 
Maitland, Rollo F. 'The Humoresque Score'. American Organist, September 1920, 331. Marks, Martin Miller. Music and the Silent Film: Contexts and Case Studies, 1895-1924. New York: Oxford University Press, 1997.

'Photoplay Reviews: Rialto - New York'. American Organist, September 1920, 332-4.

'Reel Life at the Riesenfeld Houses'. Columbia Daily Spectator, 19 July 1920, 3. Accessed 13 July 2016, http://spectatorarchive.library.columbia.edu/cgi-bin/columbia?a=d\& $\mathrm{d}=\mathrm{cs} 19200719-01.2 .22$.

'Riesenfeld's "Humoresque" Score'. American Organist, September 1920, 332.

Sauer, Rodney. 'Photoplay Music: A Reusable Repertory for Silent Film Scoring, 1914-1929'. American Music Research Center Journal 8-9 (1 January 1998): 55-76.

'Score in Detail: Humoresque'. American Organist, August 1920, 294-5.

Standard Student's Classic Album. Philadelphia, PA: Theodore Presser, 1917.

Targa, Marco. 'The Use of Cue Sheets in Italian Silent Cinema: Contexts, Repertoires, Praxis'. In The Sounds of Silent Films, edited by Claus Tieber and Anna Windisch, 49-65. New York: Palgrave Macmillan, 2014. 